\title{
ESTUDO DE MATERIAIS DE APOIO PARA REÇURSOS MUSEOGRÁFICOS DE EXPOSIÇÃO
}

Histórico

O embrião deste projeto remonta a 1992, quando deparamos com montagens de exposições itinerantes e temporárias, organizadas com coleções arqueológicas e etnográficas junto ao MAE-USP.

Nesse mesmo período, iniciamos os trabalhos voltados à concepção e montagem da exposição de longa duração Formas de Humanidade, mostra cujo enfoque apresenta as sociedades representadas nas coleções que compõem o acervo do MAE.

A grande diversidade de materiais e dimensões dos objetos que formam as coleções arqueológicas e etnográficas a serem expostas nessa mostra, assim como o significado, função e apelo estético das peças tornaram-se grandes dificuldades, pois cada objeto exigiu uma apresentação específica que garantisse o caráter de comunicação e de conservação preventiva.

A necessidade de seleção de materiais e serviços adequados à montagem dessa exposição que atendessem às exigências do projeto museográfico, levou-nos a uma pesquisa dentro de um vasto mercado. Pudemos, então, perceber a grande diversidade de materiais e serviços que poderiam estar sendo aplicados à montagem de exposições, com resultados satisfatórios.

\section{Justificativa}

Os avanços tecnológicos e a grande profusão de novos materiais e técnicas presentes no mercado são ainda desconhecidos pela maioria do pessoal envolvido em concepção e montagem de exposição no Brasil. Consideramos, então, de grande importância a aproximação desse mercado aos museus, propiciando que as nossas instituições tenham conhecimento de um universo de possibilidades a serem adequadas à museografia de exposição. Assim, a distância entre os avanços tecnológicos, os recursos museográficos e de conservação e a eficiência das nossas mostras, será cada vez menor.

Recebido para publicação em 20 de agosto de 1996
Objetivos

- Levantar um conjunto de dados que auxiliem os museus a selecionarem os materiais mais favoráveis para a montagem de exposições, visando a comunicação e conservação preventiva dos objetos;

- Contribuir para o avanço das técnicas museográficas.

\section{Procedimentos}

- Análise físico-química para medição da acidez de materiais que estão sendo utilizados em exposições e outros:

- Seleção dos testes a serem realizados no Laboratório de Conservação e Restauro do MAE/USP;

- Levantamento de serviços e coleta de materiais, amostras e dados que auxiliem a análise da aplicabilidade dos recursos às exposições;

- Análise dos materiais e registro dos dados;

- Análise museográfica dos materiais:

- Estudo das possíveis aplicações e características dos materiais/recursos

- Preenchimento de ficha padrão

- Divulgação periódica dos dados

Os dados coletados serão informatizados e organizados em forma de catálogo, seguindo o modelo de Tétrault e Williams (1993), facilitando a sua divulgação periódica.

\section{Marilia Xavier Cury* Mauricio Cândido da Silva**}

\section{Referência bibliográfica}

\section{TÉTRAULT, J.; WILLIAMS, S.}

1993 Guide de sélection des matériaux pour l'exposition, la mise en réserve et le transport. Institut Canadien de Conservation, Canada

${ }^{*}$ ) Museu de Arqueologia e Etnologia da Universidade de São Paulo.

(**) Serviço de Musealização do Museu de Arqueologia e Etnologia da Universidade de São Paulo. 